\title{
Markaların Sosyal Medyada Oluşan Sinik Tutuma Yönelik Yaklaşımları
}

\author{
Betül ÖZKAYA ${ }^{1}$ ve Yelda ÜLKER ${ }^{2}$ \\ $\ddot{\mathrm{O} z}$
}

Marka ile yaşanan olumsuz deneyimler, tatminsizlikler, güven kaybı, karșılanmamıș beklentiler tüketicilerin markaya karşı sinik tutumlar sergilemesine sebep olmaktadır. Tüketici, marka ile yaşadığı olumsuz deneyimi, sosyal medyanın kolay erişimi sayesinde diğer tüketiciler ile paylaşmaktadır. Bu durum ise marka hakkındaki olumsuz duygu ve düşüncelerin tüketiciler arasında hızla yayılmasına yol açarak marka açısından son derece yıkıcı sonuçlar doğurabilmektedir. Çalışmanın amacı, markaların sosyal medyada oluşan sinik tutuma yönelik yaklaşımlarını ayrıntılı olarak incelemektir. Çalışmada İstanbul'da gıda sektöründe faaliyet gösteren iki markanın sosyal medya uzmanları ile derinlemesine görüşme yapılmıstır. Derinlemesine görüşme için söz konusu iki markanın seçilmesinde, gida sektöründe başarılarını kanıtlamış olmaları ve hem ulusal hem de uluslararası pazarlarda faaliyetlerini sürdürmeleri gibi faktörler etkili olmuştur. Çalışma sonuçları, markaların sosyal medyada oluşan tüketici sinizmine daha fazla önem vermeleri ve sinik tutuma yönelik ne tür yaklaşımlarda bulunmaları gerektiğini göstermesi açısından önemlidir. Bununla birlikte çalışmanın hem sosyal medyada sinik tutumla karşılaşan ulusal ve uluslararası markalara 1şık tutması hem de yerli ve yabancı literatürde çok yeni bir konu olması nedeniyle daha sonra yapılacak çalışmalara altyapı oluşturması hedeflenmektedir.

Anabtar Kelimeler: Sinizm, Sinik Tutum, Marka, Sosyal Medya.

\section{The Approaches of the Brands to the Cynical Attitudes in Social Media}

\begin{abstract}
Negative experiences, dissatisfaction, loss of confidence, unmet expectations of the brand cause consumers to exhibit cynical attitudes towards the brand. Consumers share their negative experiences about a brand using social media due to its easy accessibility. This situation can cause negative feelings and thoughts about the brand to spread rapidly among consumers and can produce extremely destructive results in terms of the brand. The aim of this study is to examine the approaches of brands to cynical attitude in social media. In this study, in-depth interviews were conducted with the social media experts of two different food sector brands operating in Istanbul. Factors such as brands' proven record in food industry and their activities in international markets were significant in selecting these two brands for in-depth interview. The results of this study are important in terms of showing what kind of approaches the brands should take in face of the cynical attitudes that occur in social media and the approaches that should be taken in line with these attitudes. In addition, the study aims to shed light on both national and international brands that face the cynical attitudes in social media, and this study will establish a baseline for the future studies, thanks to its novel subject-matter.
\end{abstract}

Key Words: Cynicism, Cynical Attitudes, Brand, Social Media

\section{Atıf İçin / Please Cite As:}

Özkaya, B. ve Ülker, Y. (2020). Markaların sosyal medyada oluşan sinik tutuma yönelik yaklaşımları. Manas Sosyal Araştırmalar Dergisi, 9(1), 115-128.

\footnotetext{
1 Dr. Öğr. Üyesi - Marmara Üniversitesi İletişim Fakültesi, betulozkaya@marmara.edu.tr ORCID ID: 0000-0001-6946-9403

2 Arş. Gör. - Marmara Üniversitesi İletişim Fakültesi, yeldaulker@hotmail.com - ORCID ID: 0000-0001-8105-2686
} 


\section{Giriş}

Tutumların önemli ölçüde deneyimlerden kaynaklandığı düşünüldüğünde, tüketiciler yaşadıkları olumsuz deneyimler, tatminsizlikler, güven kaybı, karşılanmamış beklentiler, değer ve prensipler sonrasında marka hakkında olumsuz tutumlara sahip olabilmektedir. Söz konusu bu yaşananlar olunca, tüketici davranışları konusunda son yıllarda çok tartısılan ve dikkat çeken konulardan birinin de 'sinizm' olduğu ifade edilebilir.

Sinizm kavramı; bilişsel, duygusal ve davranışsal bileşenlerden oluşan olumsuz bir tutum olarak tanımlanabilir. Bununla birlikte sinizm genel olarak, güvensizlik ve şüphe duygularını içermesinin yanı sıra tatminsizlik, direnme, geri çekilme, uzaklaşma, yabancılaşmaya kadar uzanan sonuçlara da sahip bir kavramdır. Bu bağlamda, karşılıklı güven ilişkisini gerektiren marka-tüketici ilişkisinde de bu güvenin zarar görmesi ile birlikte tüketicide oluşabilecek "sinik tutum"dan söz edilebilir. Gerek marka mesajlarının gerekse de marka ile yaşanan olumsuz deneyimler, tatminsizlikler ve sonrasında oluşan sinik tutumlar ve sonuçları, markaların son yıllarda dikkatle üzerinde durması gereken konulardan birini oluşmaktadır (Güven, 2016, s. 152-154).

Literatürde tutum kavramına ilişkin pek çok tanım yer almaktadır. İnceoğluna göre(2004, s. 11) tutum, kişinin herhangi bir durum, olay ya da olgu karşısında olası davranış biçimi oluşturma eğilimidir. Bu açıdan tutum kavramının, doğrudan gözlenebilir olmasada, önceden tahmin edilen ve kişilerin seçimlerine yön veren bir yapıya sahip olduğu söylenebilir (Hogg ve Vaughan, 2006, s. 174). Tutar'a göre ise tutum, anlık olmadıkları için değişmesi nispeten zor olan inançlar ve değerlendirmeler bütünü olup, bilişsel, duygusal ve davranışsal olmak üzere üç bileşenden oluşmaktadır (2012, s. 187-193). Bu bağlamda kökeni yaklaşık M.Ö. 500’lü yıllara dayanmakta olan sinizm kavramı da tıpkı tutumda olduğu gibi bilişsel, duygusal ve davranışsal olmak üzere üç temel bileşene sahiptir (Copleston, 1993, s. 438). Sinizmin bilişsel boyutunda güvensizlik, inanmama ve şüphe kavramları, duygusal boyutunda tatminsizlik ve yabancılaşma kavramları, davranışsal boyutunda ise şikâyet, direniş ve düşmanlık kavramları ele alınmaktadır. Bir başka tanıma göre sinizm; hoşnutsuzluk, kötümserlik ve sadece kendi çıarlarını gözetme olarak nitelendirilebilir (Andersson, 1996, s.1396-1397; Andersson ve Bateman, 1997, s.450). Ayrıca sinizm, başkalarına karş1 oluşturulan olumsuz tutum olarak da tanımlanabilir. Bu bağlamda, geniş boyutlara sahip olan sinizm kavramı, din, siyasi bilimler, psikoloji ve sosyoloji gibi sosyal bilimlerin farklı disiplinlerinde çalışma konusu olmaktadır (Kalağan ve Güzeller, 2010, s. 84).

Öfke, kızgınlık, şüphecilik, aldatılma, memnuniyetsizlik, güvensizlik, hayal kırıklı̆̆ gibi kişilerin hissettikleri olumsuz duygular olarak tanımlanan sinizm kavramı ile (Chylinski ve Chu, 2010, s. 797; Çetinkaya ve Ceng, 2018, s. 168; Özler, Atalay ve Şahin, 2010, s. 48) son yıllarda tüketici davranışları alanında da sıkça karşılaşılmaktadır. Tüketim bağlamında, tüketicilerin herhangi bir marka hakkındakiolumlu veya olumsuz tüm duygu, düşünce ve davranışlarından oluşan tutum (Tosun, 2017, s. 337), tüketim alışkanlıklarını da etkilemektedir. Dolayısıyla tüketicilerin marka ile yaşadıkları olumsuz deneyimler de sinik tutumların ortaya çıkmasına neden olabilmektedir. Diğer bir ifadeyle, tüketicilerin marka hakkındaki olumsuz deneyimleri, tüketicilerin davranışlarına yansımaktadır. Örneğin; beğenmedikleri markaları boykot edebildikleri ya da diğer tüketicileri bu markalardan alşsveriş yapmamaları konusunda uyardıkları görülmektedir (Güven, 2016, s. 157). Özellikle tüketicilerin bir marka ile ilgili yaşadıkları olumsuz deneyimleri başkalarına anlatmaktan hoşlandıkları göz önüne alındığında (Canbazoğlu, 2017, s. 138), sinizmin tüketiciler arasında ağızdan ağıza iletişim yoluyla yayılabileceği söylenebilir.

İnternetin yaygınlaşması ile birlikte bilgiye ulaşmak artık günümüzde oldukça kolaylaşmıștır. Bu bağlamda, tüketicide olumsuz tutum oluşturabilecek herhangi bir bilgi, doğru olsun ya da olmasın diğer kullanıcılara neredeyse 1şık hızıyla ulaşabilmektedir (Çetin ve Toprak, 2016, s. 54-68). Markanın herhangi bir davranışından rahatsız olan tüketiciler, internet üzerinden marka karşıtı sloganlar yaratmakta, markaya yönelik iddiaları yaymakta ve hoşnutsuz marka toplulukları oluşturup toplantılar düzenlemektedir (Chylinski ve Chu, 2010, s. 796). Bu durum da marka hakkındaki olumsuz duygu ve düşüncelerin tüketiciler arasında hızla yayılmasına yol açarak marka açısından son derece yıkıcı sonuçlar yaratabilmektedir. Negatif ağızdan ağıza iletişimin kısa vadedeki sonuçlarını görmezden gelmek mümkün değildir (Cheng, Lam ve Hsu, 2006, s. 98). Diğer bir ifadeyle, tüketicideki olumsuz deneyimler, karşılanmamış beklentiler, reklam mesajlarının aldatıcılığı ve markaların etik dışı davranışları gibi unsurların tüketicide markaya karşı sinik tutum oluşmasına neden olduğu söylenebilir (Güven, 2016, s. 163). 
Kişilerdeki hayal kırıklığ1 olarak da tanımlanan sinik tutum, tüketim bağlamında tüketicilerin yaşadıkları doğrudan veya dolaylı olumsuz deneyimlerle oluşmaktadır (Güven, 2016, s. 159). Ancak markalara karşı sinik tutum oluşması için büyük bir sebebe ihtiyaç yoktur. Diğer bir ifadeyle markaların müşterilerini kaybetmesi, kendilerine kin beslenmesi ve olumsuz bir tutum oluşması için küçük bir sebep yeterlidir (Aron, 2001, s. 108). Tüketiciler, insan haklarına veya çevreye saygısızlık, etik olmayan davranışlar gibi çeşitli nedenlerden dolayı markalara karşı olumsuz tutum sergilemektedir. Bu bağlamda, o markanın ürünlerini boykot edebilir ve olumsuz duygularını çeşitli yollarla diğer tüketicilerle paylaşabilir (Çetinkaya ve Ceng, 2018, s. 171; Sandıkçı ve Ekici, 2009, s. 208;). Markaya karşı güvenini kaybetmiş olan tüketicilerin olumsuz tutumları markanın itibarı, güvenirliliği ve satışı için büyük tehdit oluşturmaktadır. Diğer bir ifadeyle, markaya karşı güvenini kaybetmiş ve sinik tutum oluşturmuş tüketici, sosyal medya aracilığıyla markaya zarar verebilmektedir (Güven,2016, s. 163). Özellikle internetin yaygınlaşması ile birlikte, tüketiciler sevmedikleri markaları cezalandırma amacıyla sosyal medyayı kullanmaktadır. Bunun yanı sıra kendisiyle benzer duygulara sahip kişileri bulabilen tüketicinin sinik tutumu, başka tüketicilere de sıçrayabilmektedir. Sosyal medyada bir araya gelen tüketiciler, markaya karşı nefret siteleri kurup, bilgi alışverişinde bulunmakta, boykot eylemleri organize etmekte ve birleşip davalar açmaktadır (Kucuk, 2007, s. 211).

Tüketicinin sinik tutum sergilediği markalardan biri olan Nike, yıllarca kötü koşullarda işçi çalıştırdığ1 ve içlerinde çocuk işçilerin de bulunması sebebi ile eleştirilmiştir. Marka sadece satın alınmayarak protesto edilmemiş, mağazalarına da fiziksel zarar verilmiştir. Bunun yanı sıra marka hakkında sosyal medyada olumsuz söylemler yayılmış ve "Just Do It!" sloganı "Just Don’t Do It" (Sadece Yapma), "Nike, Do It Just" (Nike, Adilce Yap), "Just Boycott It" (Sadece Boykot Et) gibi sloganlara dönüştürülmüş, markanın logosu ise Nazi gamalı haça benzetilmiştir. Marka, tüketicide oluşan sinik tutumu olumluya dönüştürmek için, tedarikçilerinin etik prensiplere uygun hareket etmelerini denetleyeceklerini bildirmiştir. İşçi haklarını savunan bir vakfa bağışta bulunan marka, 2005 yllında da "Şirket Sorumluluk Raporu" adı altında bir çalışma yayınlamış ve bu raporda ürünlerinin imal edildiği fabrikaların listesi ile markanın çevreye olan duyarlılı̆̆ ve işçi alımlarında izlediği yöntemlerle ilgili bilgilere yer vermiştir (Bakır ve Çelik, 2013, s. 55; BBC TURKISH, 2005; Persson, 2008, s. 49).

Günümüzde tüketicinin daha bilinçli ve sorgulayıcı olması dikkate alındığında (Güven, 2016, s. 161) yapılan araştırmalar, kişilerin olumsuz deneyim ve duygularını başkaları ile paylaşmada daha istekli olduklarını göstermektedir (Canbazoğlu, 2017, s. 139). Nutella ve Nestle markası, ürünlerinde palmiye yağ1 kullanmasından dolayı tüketicinin tepkisini çekmiştir. Palmiye yağı kullanmak için ağaçlara zarar verdiği, çevreyi kirlettiği, su, hava ve toprak kirliliğine sebep olduğu için eleştirilen markalar, tüketiciler tarafindan boykot edilmiş, markaları eleştiren bloglar açılmış, videolar yayınlanmış ve tartışma grupları oluşturulmuştur. Sonuç olarak tüketicinin tepkisi markanın, palmiye yağı kullanımı için tedbirler almasına yol açmıştır (Cova ve D'antone, 2016, s.166-192; Çubukçuoğlu, 2017, s. 173-192).

Emisyon skandalı ile tüketicinin tepkisini çeken Volkswagen markasına yönelik sinik tutum da tüketiciler arasında hızla yayılmıştır. Marka, emisyon skandalının ardından 14,7 milyar dolar ceza ödemenin yanı sıra müşterilerine sattıkları yaklaşı 475 bin otomobili geri almaya başlamıştır. Marka, itibarını korumak için problemli araçlarını toplayıp, tamir edeceğinin garantisini müşterilerine vermiştir (Özpeynirci, 2017). Bunun yanı sıra marka, sosyal medyada yapılan eleştirileri ve araç sahiplerinin sorunlarını çözmek için Iphone ve Ipad cihazlarında kullanılmak üzere ücretsiz uygulama tasarlamıştır. Ayrıca marka, Facebook hesabından "Volkswagen Emisyon Krizi”" başıı̆ı altında açıklamalara yer vermiştir. Fakat marka, diğer sosyal medya hesaplarında soruna yönelik herhangi bir paylaşımda bulunmamıştır (Esener, 2017, s. 72-73). Daha sonra ise, yeni projelerinin ve çevreci davranışlarının haberlerini sosyal medya aracılığı ile hedef kitlesiyle paylaşarak, tüketicinin takdirini kazanmayı amaçlamışıtır (Esener, 2017, s. 103).

Türkiye'de de Onur Air markası, 2010 yılında Van depremzedeleri için başlattığı yardım kampanyası ile tüketicinin olumsuz tepkisini çekmiştir. Marka, Facebook'taki her bir takipçi için depremzedelere 0.5 TL bağışta bulunacağını açıklamıştır. Böylece marka, sosyal medyadaki takipçi sayısını arttırmayı amaçlamıştır. Ancak tüketiciler bu kampanyayı beğenmemiş ve bu durumu da sosyal medyada markanın sayfasına yorum yaparak göstermiştir. Marka, sadece kendi sosyal medya sayfasında 5 saatte 300'ü aşkın olumsuz yorum almıstır. Bunun yanı sıra marka, yapılan olumsuz yorumları silerek, tüketicinin tepkisini daha da arttırmıştır. Onur Air'e olan tepki, kurumun kendi sosyal medya sayfasını aşıp farklı platformlar da hızla büyümüştür. Kampanyayı sonlandırdığını sosyal medyadan duyuran marka bu kez de üslubu sebebi ile eleştirilmiştir. Ayrıca marka, yaptığı yardımın makbuzunu sosyal medyada yayınlamıştır. Tepkilerin 
devam ettiğini gören marka yöneticileri, sosyal medya aracilığ ile tüketicilerden özür dilemiştir (Bat ve Yurtseven, 2014, s. 197-223; Çağsal, 2011).

Yukarıda verilen örnekler bağlamında, sosyal medya, hedef kitle ile çift yönlü iletişimi sağladığı için tüketicide olumsuz tutumun ortaya çıttı̆g dönemlerde stratejik bir öneme sahiptir. Özellikle söz konusu dönemlerde sosyal medyanın etkin kullanımı, bilgi kirliliğinin önlenmesini veya azaltılmasını sağlamaktadır. $\mathrm{Bu}$ nedenle, sosyal medyada fazla bilgi kirliliği olmadan krize müdahale eden markalar, sorunu firsata çevirmeyi başarmış markalardır (Akbayır ve Kuşay, 2015, s. 982). Bununla birlikte, markaların tepki çektikleri konularla ilgili sosyal medyada özür dilemesi tüketiciler tarafından olumlu karşılanmaktadır. Ancak marka tepkilere rağmen özür dilemez, kendisini düzeltmez ve memnuniyetsizlikleri sonlandırmazsa, tüketici markadan uzaklaşabilir ve tüketicide hayal kırıklığı oluşabilir (Chylinski ve Chu, 2010, s. 799). Dahası marka; şikâyet, şiddetli protestolar, toplu boykotlar, reklam tahrifleri (vandalizm), negatif ağızdan ağıza pazarlama, markayı terk etme, intikam ve dikkatli satın alma davranışları sergileme gibi eylemlerle de karşılaşılabilir (Güven, 2016, s. 167). Dolayısıyla pazarlama iletişimi, müşteri sadakati ve müşteri memnuniyeti gibi hayati konularda hiçbir masraftan kaçınmayan markaların, bu tür masrafları boşa çıarma potansiyeline sahip sinik tutumları önceden fark edip tedbirlerini almalı ve tüketiciyi ikna edip olumlu tutum oluşturmaya çalışmalıdır. Eğer tüketicinin sinik tutumunu, markalar hızlı ve doğru bir şekilde engelleyemez ise, bu tutum diğer tüketicilere de yayıllp domino etkisi yaratabilir. Tüm bunlara ek olarak, markanın tepki çeken durumu uzun süre dillendirmemesi ve tüketicinin ilgisini başka konulara yönlendirmesi de önemlidir (Çetin ve Toprak, 2016, s. 57-66).

İnsanların öfke, kızgınlık, memnuniyetsizlik gibi olumsuz duygularının tüketim davranışlarına yansıdığ1 bilinmektedir. Bu bağlamda, marka ile yaşanan olumsuz deneyimler, markanın etik dışı davranışlarda bulunması tüketicinin markaya karşı sinik tutumlar sergilemesine sebep olmaktadır. Tüketici, marka ile yaşadığı olumsuz deneyimi, sosyal medyanın hızlı ve kolay erişimi sayesinde diğer tüketiciler ile paylaşabilmekte ve markayı krize sürükleyebilmektedir (Çetinkaya ve Ceng, 2018, s. 168). Bu çalısma, markaların sosyal medyada oluşan sinik tutuma yönelik yaklaşımlarını ortaya koymayı amaçlamaktadır. Çalışma sonuçları, markaların sosyal medyada oluşan tüketici sinizmine daha fazla önem vermeleri ve sinik tutuma yönelik ne tür yaklaşımlarda bulunmaları gerektiğini göstermesi açısından dikkat çekicidir. Bununla birlikte çalışmanın hem sosyal medyada sinik tutumla karşılaşan ulusal ve uluslararası markalara 1şık tutması hem de yerli ve yabancı literatürde çok yeni bir konu olması nedeniyle daha sonra yapilacak çalışmalara altyap1 oluşturması hedeflenmektedir.

\section{Yöntem}

Markaların sosyal medyada oluşan sinik tutuma yönelik yaklaşımlarının incelendiği bu araştırmada niteliksel araştırma yönteminden yararlanılmıştır. Niteliksel araştırma yöntemi, anlamlı bir şekilde sayılarla ifade edilemeyen verilerin toplanması, analiz edilmesi ve yorumlanmasını içerir (Kurtuluş, 2010, s. 35).

\section{Evren - Örneklem}

Yapılan araştırmada, olasılığa dayalı olmayan (tesadüfi olmayan) örnekleme yöntemlerinden yargisal örnekleme yöntemi kullanılmıştır. Yargısal örnekleme yöntemi, araştırmacının araştırmanın amacına uygun olarak belirlediği bir yöntemdir (Kavak, 2013, s. 225).

Örneklem seçimi için A.L.F.A. (Actionable, Leader, Fast, Ambitious) Awards 2017 "Müşteri Deneyimini En İyi Yöneten Markalar" ödülünü alan (Marketing Türkiye, 2017) ve gida sektöründe faaliyet gösteren markalar baz alınmış ve bu markalar arasından dört markaya derinlemesine görüşme talebinde bulunulmuştur. Ancak bu dört markadan sadece ikisi görüşme talebine olumlu yanıt vermiştir. Patton'un nitel araştırma yöntem ve tekniklerinin kullanıldığı araştırmalarda bazen örneklem, yargisal örnekleme yöntemine göre seçilmiş bir kişi de olabilir (1990 Akt: Türnüklü, 2000, s. 548) görüşünden yola çıkılarak araştırmada iki markanın ele alınmasına karar verilmiştir. Bu bağlamda derinlemesine görüşme, İstanbul'da gıda sektöründe başarılarını çeşitli ödüller alarak kanıtlamış ve hem ulusal hem de uluslararası pazarlarda uzun yıllar faaliyet gösteren iki markanınsosyal medya uzmanlan ile gerçekleştirilmiştir.

Niteliksel araştırmalarda geçerlik, araştırmacının araştırdığı olguyu ya da konuyu olduğu gibi ve objektif olarak gözlemesi anlamına gelmektedir (Kirk ve Miller, 1986 Akt: Yıldırım ve Şimşek, 2011, s. 255; Türnüklü, 2000, s. 552). Yapılan araştırmada, seçilen örneklemin ana kütleyi temsil edemeyecek kadar küçük olması ve elde edilen sonuçların istatistiksel açıdan geçerlikten yoksun olması nedeniyle söz konusu sonuçlar, araştırmacı tarafindan yorumlanmıştır. 


\section{Veri Toplama Araçları}

$\mathrm{Bu}$ araștırmada, markaların sosyal medyada oluşan sinik tutuma yönelik yaklaşımları derinlemesine görüşme tekniği kullanılarak incelenmiştir. Araştırmada, zaman ve maliyet gibi kısıtlamalardan dolayı İstanbul'da gıda sektöründe faaliyet gösteren iki markanın sosyal medya uzmanları ile derinlemesine görüşme yapılmıştır. Derinlemesine görüşme için söz konusu iki markanın seçilmesinde, gıda sektöründe başarılarını kanıtlamış olmaları ve hem ulusal hem de uluslararası pazarlarda faaliyetlerini sürdürmeleri gibi faktörler etkili olmuştur.

Uzman görüşünü, sektörü ve konuyu anlamak için yapılan derinlemesine görüşme tekniğinde katılımcının alışkanlıklarını, inanç, tutum, derin duygu ve düşüncelerini ortaya çıkarmak amaçlanmaktadır (Kurtuluş, 2010, s. 45; Tosun vd., 2018, s. 594). Derinlemesine görüşme tekniğinin seçilmesinin nedeni ise, sosyal medyada sinik tutum sergileyen tüketicilerle karşılaşan markaların sosyal medya uzmanlarının görüşlerine yer vermek ve bu konuda derinlemesine bilgiler elde ederek karşılaştırmalar yapmaktır.

Araştırma kapsamında, markaların sosyal medyada oluşan sinik tutuma yönelik yaklaşımlarına ilişkin detaylı bilgilere ulaşmak amacıyla derinlemesine görüşmelerde yapılandırılmış sorulara yer verilmiştir. Soruların ilgili içeriği yansıttığı ve görüşülen katıllımcıların verdiği yanıtlarda samimi ve içten oldukları varsayılmaktadır. Katılımcılara açı uçlu 18 adet soru sorulmuş ve gerektiğinde katılımcıya "konuyu biraz daha açar mısınız?", "örnek verebilir misiniz?” şeklinde sorular yöneltilmiştir. Ayrıca, derinlemesine görüşme yapilırken katılımcıların kendilerini rahat hissetmesi için doğal bir ortam oluşturularak konuşmanın sohbet şeklinde ilerlemesi amaçlanmıştır (Bal, 2013, s. 75).

Genel olarak derinlemesine görüşmeler, konunun genişliğine bağlı olarak 30 dakika ile 2 saat arasında değişen sürelerde gerçekleştirilmektedir (Kurtuluş, 2010, s. 46). Bu çalışmada her bir sosyal medya uzmanı ile yapılan yaklaşık birer saatlik görüşmelerde, hazırlanan 18 soru sorulmuş ve alınan yanıtlar ses kayıt cihazı kullanılarak kaydedilmiştir. Ses kayıtları daha sonra deşifre edilerek yazılı metin haline getirilmiştir.

$\mathrm{Bu}$ çalışmada derinlemesine görüşmeye katılan katıllımcılar, firma isimlerinin açılanmasına izin vermedikleri için bağlı bulundukları kurumlar belirtilmeyip katıllımcılara ait kodlama tekniği kullanılmıştır. $\mathrm{Bu}$ bakımdan ilk görüşmenin yapıldığı katıllımc1 K1, ikinci görüşmenin yapıldığ1 katılımc1 ise K2 olarak değerlendirilecektir. Markaların sosyal medyada oluşan sinik tutuma yönelik yaklaşımlarını ayrıntılı olarak tartışmayı ve tanıtmayı amaçlayan bu çalışmada derinlemesine görüşme soruları Chylinski ve Chu'nun (2010) yaptığ1 "Consumer Cynicism: Antecedents and Consequences" başlıklı çalışması, Helm'in (2004) yaptığ "Cynics and Skeptics: Consumer Dispositional Trust" başlıklı çalışması, Güven’in (2016) yaptı̆̆1 "Tüketimde Sinik Tutum: Tüketici Sinizminin Sebep ve Sonuçları" başlıklı çalışması ile Çetinkaya ve Ceng'in (2018) yaptığ1 “Türkiye'deki Black Friday Etkinliğinin Tüketici Sinizmi Bağlamında Bir Değerlendirmesi” başlıklı çalışmasından yararlanılarak hazırlanmıştır. 08.11.2018-18.11.2018 tarihleri arasında oluşturulan derinlemesine görüşme soru formunda şu sorulara yer verilmiştir;

1. Genel olarak markanız hakkında bilgi verir misiniz?

2. Markanızın faaliyet gösterdiği ulusal ve uluslararası pazarlardaki yeri hakkında bilgi verir misiniz?

3. Marka ve tüketici arasındaki ilișkilerin kalitesi konusunda sizce en belirleyici faktörler nelerdir?

4. Markanızla tüketiciler arasındaki ilişkilerin kalitesinin arttırılması konusunda neler yapıyorsunuz?

5. Markanızla tüketiciler arasındaki ilişkilerin kalitesinin artması markanıza ne gibi katkılar sağlamaktadır?

6. Markanızla tüketiciler arasındaki ilişkinin kalitesinin artması, rakiplerinizle olan ilişkilerinize nasıl yansimaktadir?

7. Marka ve tüketici ilişkilerinin önem kazandığı günümüzde rakipleriniz karşısında avantaj sağlamak için neler yapıyorsunuz?

8. Sosyal medyanın etkili kullanıldığı günümüzde markanızla tüketiciler arasında karşılıklı etkileşim ve güven duygusu oluşturmak için ne gibi stratejiler belirliyorsunuz?

9. Karşılıklı güven ilişkisini gerektiren marka-tüketici ilişkilerinde stratejik bir varlık olan güvenin zarar görmesiyle birlikte tüketicide oluşabilecek sinik tutumlar ile ilgili düşünceleriniz nelerdir?

10. Tüketicilerin markanıza yönelik olumsuz deneyimler, karşılanmamış beklentiler ve tatminsizlikler yaşaması sonucunda sosyal medyada sergiledikleri sinik tutumlar hakkında bilgi verir misiniz? $\mathrm{Bu}$ tür durumlar karşısında nasıl bir strateji ya da eylem planı izliyorsunuz? 
11. Markaların insan haklarına veya çevreye saygısızlık, etik olmayan davranışlar gibi çeşitli nedenlerden dolayı tüketicilerin, sosyal medyada sinik tutumlar sergilemeleri konusunda düşünceleriniz nelerdir?

12. Markanızla ilgili gerek reklam mesajlarının içeriği gerekse reklamlarda kullanılan dil açısından hangi unsurlara dikkat ediyorsunuz? Bu reklamlar konusunda tüketicilerin görüş ve yorumlarnnı dikkate aliyor musunuz?

13. Sinik tutum sebepleri arasında görülen reklam iletişiminde aldatıcllk konusu ile ilgili düşünceleriniz nelerdir?

14. Reklam mesajlarının tüketiciler üzerinde yarattığı olumsuz izlenimler ve sonrasında oluşan sinik tutumlar ve bunların sonuçlarını nasıl değerlendiriyorsunuz?

15. Sosyal medyada markanıza yönelik sinik tutumların tespiti ile ilgili çalışmalarınız var mı? Varsa bunlar nelerdir?

16. Sosyal medyada sinik tutuma sahip tüketicilerin önemsenmedikleri ya da haklarının ciddiye alınmadığı şeklindeki düşüncelerinin önüne geçmek için onlara sorunlarını dile getirecek ne gibi imkânlar sağliyorsunuz?

17. Sosyal medyada markanıza yönelik sinik tutumların oluşmasını önleyici çabalarınız var mı?

18. Sosyal medyada sinik tutum sonucu oluşacak direnişi nötralize edebilecek ne tür önlemler alıyorsunuz?

\section{Verilerin Analizi}

Araşıırmada veri toplama araçlarından elde edilen veriler betimsel analiz yaklaşımı kullanılarak analiz edilmiştir. Betimsel analiz yaklaşımına göre, elde edilen veriler daha önceden belirlenen temalara uygun olarak düzenlenmekte ve özetlenerek yorumlanmaktadır (Yıldırım ve Şimşek, 2011, s. 239).

\section{Bulgular}

İstanbul'da g1da sektöründe faaliyet gösteren iki markanın sosyal medya uzmanları ile 20.11.2018 tarihinde yapılan derinlemesine görüşmede elde edilen bulgular; markanın tanınması, marka ve tüketici arasındaki ilișkinin yürütülmesi, sosyal medyada markanın sinik tutuma yönelik yaklașımları, sosyal medyada markanın sinik tutum ortaya çıkmadan ve çıktıktan sonra gösterdiği çabalar olmak üzere dört başıı altında aşağıda kategorilendirilerek sunulmaktadır;

\section{Katılımcı Markalar Hakkında Bilgiler}

Derinlemesine görüşmeye katılan K1, markalarının gida sektörünün liderleri arasında yer aldığını belirterek yurt içinde 6 , yurt dişında 4 fabrikada bisküvi, çikolata ve kek kategorilerinde yüzlerce çeşit ürün ürettiklerini ifade etmiştir. Topluma değer katarak bir dünya markası olmaya odaklanan ve ürünlerini Türkiye ile birlikte Orta Doğu, Orta Asya, Avrupa, Afrika, Amerika ve Rusya gibi dünyanın dört bir yanındaki tüketicilerle buluşturan bir marka olduklarını belirten K1, tüketicilerin mutlu olmasını önemsediklerini vurgulamıştır. K2 ise tamamı yerli sermayeye sahip ve gıda sektöründe uzun yıllar hizmet veren markalarının Türkiye pazarında yenilikçi ürünler ile inovasyon ödülleri aldığını ifade etmiştir. Dijital gelişmelere önem veren, gündemi yakalamaya çalışan ve yenilikçi ürünler üreten bir marka olduklarını söyleyen K2, 2018 yilından beri Avrupa ve Orta Doğu ülkelerine ihracat yapmaya başladıklarını belirtmiştir.

\section{Marka ve Tüketici Arasındaki İlişkinin Yürütülmesi Hakkında Bilgiler}

Derinlemesine görüşmeye katılan K1, marka ve tüketici arasındaki ilişkilerin kalitesi konusunda en belirleyici faktörlerin 'güven' ve 'şeffafllk' olduğunu belirtmiştir. Aynı zamanda markaların tüketici ile olan ilişkilerini şeffaflık ve güven üzerine kurduklarında bu durumun tüketicide marka bağlllı̆̆ oluştururken markanın imajını da olumlu yönde etkilediğini vurgulamıştır. K1, tüketiciler ile olan ilişkilerinin kalitesini arttırmak için faaliyet gösterdikleri alanda birinciliği hedefleyerek en iyiyi, en yeniyi en önce sunma gayretiyle çalıştıklarını; tüketici araştırması yaparak ihtiyaç ve beklentilerini karşılamayı, onları daha iyi tanımayı, araştırma sonuçları ve elde edilen geri bildirimler doğrultusunda geliştirdikleri ürünler ile onları mutlu etmeyi, onlarla olan bağlarını güçlendirmeyi amaçladıklarını vurgulamışır. Diğer yandan K1, marka ile tüketiciler arasındaki ilişkilerin kalitesinin artmasının markalarına; tüketicilerin istek ve arzularını tatmin ederek pazar paylarının artması, yatırımcı gözünde yatırım yapılmaya değer bir şirket olarak konumlandırılma, sürdürülebilir karllık ve büyüme, ürünlerinin kalitesinin ve rekabet güçlerinin gelişmesi, tedarik zincirinde doğabilecek riskleri zamanında tespit ederek uluslararası standartların gerektirdiği 
kurallar çerçevesinde yönetme gibi konularda katkı sağladığını ifade etmiştir. Bununla birlikte K1, tüketici tatmini ile birlikte gelen büyük pazar payının sektörü değiştirme ve dönüştürme gücüne sahip olmalarını sağlarken, rakiplerini de daha iyi olmak için çalışmaya teşvik ettiklerini ve onların dönüşümüne katkıda bulunduklarını belirtmiştir. K1, rakipler karşısında avantaj sağlamak için de yenilikçi süreçler geliştirerek firmanın faaliyetlerini daha verimli hale getirdiklerini ve daha az kaynak tükettiklerini ifade etmisstir. Ar-Ge ve inovasyon süreçleri sayesinde ürün yelpazelerini genişleterek küresel ve yerel ölçekte daha çok tüketiciye ulaştıklarını, bu sayede hem tüketicilerin ihtiyaç ve beklentilerinin karşılanmasına katkıda bulunduklarını hem de rekabet güçlerini arttırdıklarını söylemiștir. Bununla birlikte tüketicilerin talep ve ihtiyaçları doğrultusunda kaliteden ödün vermeden yeni ürün geliştirdiklerini ve mevcut ürünlerde iyileştirme projeleri yaptıklarını belirten K1, sürdürülebilirliği de iş yapış biçimlerinin ayrılmaz bir parçası olarak gördüklerini vurgulamıştır.

Derinlemesine görüşmeye katılan K2 ise, marka ve tüketici arasındaki ilişkilerin kalitesi konusunda en belirleyici faktörlerin 'güven' ve 'şeffaflık' olduğunu ifade etmiştir. K2, tüketiciler ile olan ilişkilerinin kalitesini arttırmak için mümkün olduğunca onlarla çok hızlı bir şekilde iletişime geçtiklerini ve onlara yaşadığı herhangi bir olumsuz deneyimi marka ile paylaştıkları için teşekkür ettiklerini belirtmiştir. Aynı zamanda tüketicinin yaşadığı olumsuz deneyimi marka ile paylaşmasının kendileri için büyük bir firsat olduğunu söyleyen $\mathrm{K} 2$, ancak tüketicinin yaşadığı olumsuz deneyimi marka ile paylaşmaması durumunda ise markanın yaşanan sorundan haberinin olmayacağını ifade etmiştir. Diğer taraftan tüketicinin yaşadığı olumsuz deneyimi, marka ile paylaşmasının markanın hatasını telafi etmesine ve müşteri memnuniyetine çevirme şansı elde etmesine yol açacağını belirten K2, tüketicilerden gerekirse özür dilemenin, önemsendiklerini hissettirmenin hatta onları dinlemenin tüketicilerin olumsuz algisını olumluya çevirebildiğini anlatmıştır. Bununla birlikte $\mathrm{K} 2$, markaları ile tüketiciler arasındaki ilişkilerin kalitesinin artmasının her şeyden önce tüketiciler ile doğrudan iletişim içinde olan ve böylece tüketicilerin kızgınlı̆ı̆nı, mutluluğunu ilk hisseden sosyal medya uzmanlarını memnun etmesi yönünde katkı sağladığını belirtmiştir. Öte yandan K2, rakipler ile doğrudan ya da dolaylı bir şekilde ilişki içinde olmadıklarını belirterek rakipler karşısında avantaj sağlamak için tüketiciler ile mümkün olduğu kadar en hızlı bir şekilde iletişime geçmenin, onları anlamaya, dinlemeye, önemsemeye ve takip etmeye çalışmanın markaya karşı olumlu tutum sergilemelerine sebep olacağının farkında olduklarını ifade etmiştir. Örneğin sosyal medyadan takip ettikleri tüketicilerin -anlık olarak akışlarına düştügü taktirde- doğum günlerini kutladıklarını, hasta olduklarında "geçmiş olsun" mesajı yazdıklarını belirtmiştir. Ayrıca tüketiciler, markaları hakkında olumlu bir bildirimde bulunduklarında ise onları mutlu edecek ya da onların hoşuna gidecek bir mesaj ile iletişime geçtiklerini belirtmiş ve sosyal medyada tüketici "bu markayı çok seviyorum" gibi bir mesajı doğrudan markaya yazmasa bile "afiyet olsun" mesajı yazdıklarını ifade etmiştir.

\section{Sosyal Medyada Markanın Sinik Tutuma Yönelik Yaklaşımları Hakkında Bilgiler}

Derinlemesine görüşmeye katılan K1, markalarının iletişim yönetimi stratejisinin temellerini; vizyoner bir yaklaşımla, yeni iletişim ortamlarını ve dijital dünyanın yeniliklerini nitelikli projelerde uygulayan, popüler olanın değil henüz düşünülmemiş olanın yanında olan bir çatı marka olma hedefi oluşturduğunu belirtmiştir. Bu doğrultuda hazırladıkları sosyal medya yönetim kılavuzunun, markanın değerleri, vizyonu ve hedefleri ile ilgili yapılmakta olan stratejik çalışmaların bir ürünü olduğunu vurgulamıştır. 21. yüzyılın en etkili iletişim araçlarından sosyal medyada nasıl var olmaya devam edecekleri, bu mecrada risk ve krizleri nasıl yönetecekleri konusunda ayrı bir yönetim kurullarının olduğunu ifade etmiştir. Bununla birlikte stratejilerinin temelini ise, her zaman ve her koşulda doğruyu ve iyiyi pusula kabul etmelerinin, sadece ülkemizde değil, dünyadaki en iyi uygulamaları hayata geçirme motivasyonlarının, zamanın ruhunu iyi okuyarak firmanın var olan değerlerine yenilerini ekleyerek o değerleri kurum kültürüne ve uygulamalara dahil etmelerinin ve iletişim dillerindeki samimiyetin oluşturduğunu belirtmiştir. Özellikle son ylllarda dünyada ve ülkemizde güçlü büyüme trendine sahip sosyal medyada da ilkelerine ve marka değerlerine uygun şekilde yer almaya devam edeceklerini söyleyen K1, diğer mecralarda olduğu gibi sosyal medya iletişimlerinde de süreçleri hassaslıkla yönettiklerini, gerekli durumlarda danışmak ya da onay almak için yönetim kurulu ile iletişime geçtiklerini ve bu süreçleri daha sistemli ve öngörülebilir bir yaklaşımla yürüttüklerini ifade etmiştir. Diğer yandan K1, sosyal medyada tespit edilen içeriğin krize dönüşme riski ve krize dönüştügünde oluşturacağı etkiyi düşünerek hazırladıkları sosyal medya yönetimi kılavuzundaki "Risk Seviyesi Matrisi"nde, potansiyel risklere karsı nasıl hareket edeceklerini belirlediklerini belirtmiştir. Aynı zamanda firmanın kontrolü dışında gelişen olaylar, internetteki yorumlar, yazılar, hızla yayılan ifadeler, iddialar ve paylaşımlarla karşılaşıldığında önceden hazırlıklı olmanın; krizin oluşumunu ya da büyümesini 
engellemede ve bazı durumlarda krizi firsata çevirmede kullanılabilecek en önemli avantaj olduğunu vurgulamıştır. Bu bakımdan her krizin kendi dinamikleriyle incelenmesi yanında krizin derecelendirilmesi için de kullanılan görsel materyal, metnin yazım özellikleri, dili, yayılım hızı, içeriği, içerik paylaşan kişi/kurumun niteliğinin bilinmesi gerektiği ifade edilmiştir. Videolar ve sosyal mecralar için rakamsal bazı değerler üzerinden ilerlemenin önemli olduğunu vurgulayan K1, krizi derecelendirmede sadece yayılım rakamlarına bağlı kalmanın yeterli olmayabileceğini, durumu 360 derece ele alıp değerlendirmenin ve hızlı aksiyon almanın gerektiğini belirtmiştir. Öte yandan pazarlama ve iletişim çalışmalarını "iletişimde öncelik, toplum sağlığını korumak ve geliştirmektir” anlayışına bağlı kalarak sorumlu bir şekilde yürüttüklerini söyleyen K1, Türk gıda sektörünün standartlarının belirlenmesinde uzun yıllar önemli rol oynayan markalarının, bu alandaki kuralları dünya standartlarına ulaştırmak için Türk gıda sektöründe bir ilk olarak "sorumlu beslenme" prensiplerini oluşturduğunu ifade etmiştir. Söz konusu prensipleri, "Sorumlu Beslenme İletişimi Kılavuzu" altında bir araya getirerek, Türkiye'de bu alanda bir kılavuz hazırlayan ilk Türk gıda şirketi olma özelliğine sahip olduklarını belirten K1, bu kılavuzda şirket ve markalarının sorumlu iletişim prensiplerinin yer aldığını ve çocuklara yönelik iletişimde bazı taahhütlerde bulunduklarını söylemiştir. Sorumlu beslenme prensipleri ile dünya standartlarında güvenli, yüksek kalitede ve lezzetli gıdalarının yaygınlaştırılmasını hedeflediklerini belirten K1, tüketicilere bilinçli seçim yapmanın önemini vurguladıklarını, reklamlar, sponsorluklar, çekilişler, ödüller ve benzer promosyonlar gibi aktiviteleri de içeren pazarlama iletişimi çalışmalarında da söz konusu prensipleri göz önünde bulundurduklarını ifade etmiştir. Çocuklara yönelik reklam ve iletişim araçlarıyla ilgili olarak belirli prensiplerin açıklandığı söz konusu kılavuzda, reklamların ebeveyn otoritesine zarar vermeyeceği, çocukları ürün kullanımının potansiyel faydalanı konusunda yanlış yönlendirmeyeceği, sağlıklı beslenme şekillerini ve fiziksel aktiviteyi özendirecek yönde olacağ taahhüt edilmiştir. K1, tüm süreçlerde olduğu gibi reklam faaliyetleri ile ilgili her yıl düzenli olarak araştırma şirketleri ile tüketicilerin görüş, yorum ve önerilerinin alındığını ve geri bildirimlerin her birini de iş süreçlerine dahil ederek daha iyisi için çalışıklarını vurgulamıştır. Tüm bunlara ek olarak K1, reklamın toplumsal yararları kadar, neden olduğu zararlar ve olumsuz etkilerin de büyük tartsşma konusu olmaya her zaman devam edeceği düşüncesinde olduğunu belirterek reklamlara ilişskin eleştirilerin; kıt kaynakların israfına yol açmak, fiyatları artırmak, sahte toplumsal değerler ve kalıplaşmış kişiler yaratmak, çocuklar üzerinde olumsuz etkide bulunmak, insanlanın pasif, açgözlü, şehvet düşkünü, tek düşüncesi satın alma ve tüketme olan kişiler haline getirmek, onların duygularını sonuna kadar sömürmek gibi başlıklarda toplanabileceğini ifade etmiştir. Bu durumda reklamın hukuki alt yapısının daha özel bir anlam kazandığını belirten K1, tüketicilerin yanıltılma, aldatılma ve kandırılmalarına karşı reklam hukukunun bilinmesi ve geliştirilmesinin zorunluluk halini aldığını; aldatıcı reklamlarla mücadelenin, reklamların hukuka uygunluğu ve reklam denetimindeki hukuki alt yapının gelişmesinin her zaman destekçisi olacaklarını vurgulamıştır. Ayrıca K1, kuruldukları günden bu yana en önemli paydaşlarından biri olarak gördükleri tüketicilerine mutlu anlarında eşlik ettiklerini, tüketicileri ile aralarında bulunan güven ilişkisine büyük önem verdiklerini, onların beklentilerini en üst seviyede karşılamak ve memnuniyetlerini sürekli artırmak için çalıştıklarını belirterek tüketici geri bildirimlerini önemsediklerini, tüm bildirimleri kayıt altına alarak incelediklerini ve bildirimler sonrası gerekli düzeltici faaliyetleri gerçekleştirdiklerini ifade etmiştir.

Derinlemesine görüşmeye katılan K2 ise, sosyal medya hesaplarını ilk açtıklarında markalarının tüketiciler tarafindan erkek olarak algılandığını ancak hedef kitlelerini kadınlar oluşturduğu için sosyal medyadan yaptıkları iletişim ile markayı dişileştirdiklerini ve onlarla bir marka olarak değil de, sanki kendilerinden biriymiş gibi samimi bir iletişim kurduklarını belirtmiştir. Bununla birlikte özellikle son y1llarda markalarının dünyada ve ülkemizde güçlü büyüme trendine sahip olduğunu ifade eden K2, günümüzde tüketicilerin "daha fazla hakll” olduğunu, özellikle tüketicilerin elinde sosyal medya gibi güçlü bir mecra bulunduğunu ve bu mecranın kontrol altına alınabilmesinin oldukça zor ancak gözlemlenebilir olduğunu söyleyerek, tüketicilerin kendilerine hızlı dönüş yapılmaması ya da şikayetlerinin giderilmemesi konusunda sergiledikleri sinik tutumları gözlemlediklerini vurgulamıştır. Bu bağlamda K2, tüketicinin sosyal medyada bir paylaşımda bulunduktan sonra bu paylaşımın hızla yayılabileceğinin ve markaya zarar verebileceğinin farkında olarak söz konusu paylaşımı markaya karşı bir tehdit olarak da kullanabildiğini söylemiştir. Diğer taraftan K2, sosyal medyada iletişim halinde oldukları tüketicileri ikiye ayırarak bazı tüketicilerin iyi niyetli olarak marka ile yaşadıkları olumsuzlukları kendileri ile direkt mesaj olarak paylaştıklarını ve direkt mesaj olarak gelen bu paylaşımlanı bir tek kendilerinin görebildiklerini; bazı tüketicilerin ise marka ile yaşadıkları olumsuzlukları direkt mesaj ile paylaşmak yerine herkesin görebileceği bir şekilde paylaştıklarını belirtmiştir. Öte yandan tüketicilerin, sosyal medyada yazdıkları olumsuz yorumların marka tarafından silinip silinmediğini belirli aralıklarla kontrol ettiklerini ve bazı tüketicilerin 
markaya hakaret edebilecek kadar kendilerinde hak görebildiklerini ifade etmiştir. K2, kurum gereği tüm tüketicilerine şeffaf davrandığını, gelen olumsuz yorumları silmeden tuttuklarını, sadece hakaret, küfür gibi etik değerlere uygun olmayan yorumları sildiklerin belirtmiştir. Ayrıca K2 bazen bir şirket sahibinin, bazen de bir şirket çalışanının yaptığı ufak bir yanlışın bile sosyal medyada önce onlarca, sonra yüzlerce, binlerce ve sonunda milyonlarca kişinin marka hakkında sinik tutum sergilemesine sebep olabildiğini vurgulamıştır. $\mathrm{K} 2$, gerek reklam mesajlarının içeriği gerekse reklamlardasamimi olduğu kadar güven veren bir dil kullanmaya çalıştıklarını belirterek tüketicilerden gelen öneri, yorum, istek ya da şikayetleri dikkate aldıklarını söylemiştir. Gerçek olmayan iletişim vaatlerinin tüketiciyi her dönem kızdırdığını belirten K2, özellikle tüketicilerin elinde sosyal medya gibi güçlü bir mecra varsa hiçbir markanın reklam iletişiminde tüketicisini aldatmaya cesaret edemeyeceğini, ediyorsa da sosyal medya üzerinden "linç" edilmeyi göze aldığını ifade etmiştir. Tüketicileri aldatmak bir yana, onların reklam hakkında olumsuz düşüncelerinin olması bile markaların iletişimlerine eskisinden çok daha fazla dikkat etmelerine yol açtığını vurgulayan K2, günün sonunda binlerce sosyal medya kullanıcısından olumsuz dönüş almayı hiçbir iletişimcinin istemeyeceğini söylemiştir. Tüm bunlara ek olarak $\mathrm{K} 2$, en başarllı denilebilecek reklam mesajına bile mutlaka olumsuz izlenimi olan tüketiciler çıkacağını ve bu nedenle de risk alabilecek, toplumun bazı kesimlerini kızdırabilecek iletişimlerden kaçınmanın yararlı olacağını belirtmiştir.

\section{Sosyal Medyada Markanın Sinik Tutum Ortaya Çıkmadan ve Çıktıktan Sonra Gösterdiği Çabalar Hakkında Bilgiler}

Derinlemesine görüşmeye katılan K1, sosyal medyada markalarına yönelik sinik tutumların tespiti ile ilgili araştırma ve analiz yapıp eş zamanlı paylaşan bir ajans ile çalışıklarını ifade etmiştir. Doğru beslenme alışkanlığ1 edinmenin ve gida güvenliği konularında bilgilenmenin toplum sağlığ1 açısından önemli olduğunu söyleyen $\mathrm{K} 1$, sahip oldukları sorumluluk bilincinin, pazarlama ve iletişim alanındaki tüm çalışmalarına yansıdığını belirtmiştir. Sadece kendilerini doğru anlatmak için değil, tüketicileri de doğru tanımak için çaba sarf ettiklerini söyleyen K1, tüketicilerle aralarındaki güven duygusunu pekiştirmek için ürünlerinin tamamında Türk Gıda Kodeksi Etiketleme Yönetmeliği gereğince gıdanın içeriğine, niteliğine ve üretimine yönelik verileri şeffafça paylaştıklarını vurgulamışır. Aynı zamanda tüketici geri bildirimlerini kayıt altına alarak değerlendirdiklerini ve gerekli düzenlemeleri yaptıklarını belirtmiştir. Bununla birlikte sosyal medya ilkeleri sayesinde sinik tutumları önleyici tutum sergilemek için her zaman çalş̧tıklarını söyleyen K1, iletişimin ilk adımının dinlemek olduğu düşüncesinden yola çıkarak tüketicilerden gelen öneri ve geri bildirimleri önemsediklerini açıklamıştır. Başkalarından öğrenmeye açık oldukça, başarılarını daha da arttıracaklarına inandıklarını söyleyen K1, insanlarla ilişkilerinde saygılı ve yapıcı davrandıklarını, insan ve hayvan haklarını, cinsiyet eşitliğini, demokrasinin temel değerlerini gözettiklerini, telif haklarına ve etik kurallara uyduklarını ifade etmiştir. Bunlara ek olarak ifade özgürlüğ̈ne inanan, değerlerini, itibarlarını ve hukuki haklarını ihlal etmeyen her türlü ifadeyi hoşgörüyle karşıladıklarını, konvansiyonel iletişim alanında benimsedikleri kurum kültürünü, dijital mecralarda da koruduklarını ve verdikleri kararlarda yol gösterici olarak gördüklerini belirtmiştir. Ayrıca, sosyal medyada resmî açıklamalar dışında, doğruluğu teyit edilmemiş bilgileri paylaşmadıklarını, bilgilerinin gizliliğini koruduklarını ve çalışma arkadaşlarını, kişisel bilgilerini saklamaları yönünde teşvik ettiklerini ifade etmiştir. Diğer yandan rekabet koşullarının hızla değiştiği günümüz şartlarında, yeni bir iletişim evreninde olduklarını belirten K1, sürekli büyüyen ve daha geniş kitlelere ulaşan bir kurum olarak müşterilerini dinlediklerini ve memnuniyetlerini üst seviyede tutmaya çalıştklarını belirtmiştir. Öte yandan sosyal medyada marka ve itibar yönetiminde, yönlerini belirleyecek ilkeler ve olmazsa olmazları olduğunu vurgulamıştır. Sosyal medyada bir krizle karşılaşıldığında alınacak her kararın markalarını ve hatta diğer grup şirket markalarını dahi etkileyeceğini göz önünde bulundurarak medya ve pazarlama iletişimi yönetim ekiplerinin, sosyal medya yönetim kurulu ile dayanışma içinde olduğunu ifade etmiştir. Bununla ilgili risk analiz diyagramları ile risk analizini doğru yapabilmek ve hızlı çözümler üretebilmek için birimlerle her zaman iletişim içinde olduklarını söylemiştir.

Derinlemesine görüşmeye katılan K2 ise "monitoring" olarak adlandırılan "dinleme ve takip etme" yazılımları kullandıklarını belirterek, yazılıma verdikleri anahtar kelimeler ile markalarına yönelik sinik tutum sergileyen tüketicilerle iletişime geçtiklerini ve onların yaşadıklanı olumsuz deneyimleri olumluya çevirmeye çalıştıklarını ifade etmiştir. Bununla birlikte K2, sosyal medya hesaplarına gelen her mesajı mutlaka cevapladıklarını, olumsuz yorumları silmediklerini, sosyal medyadan iletişimi "çağrı merkezine" yönlendirdiklerini belirtmiştir. Burada konuyla ilgili ve bilgili personellerinin tüketiciler ile iletişime geçtiğini ifade ederek sosyal medyayı iletişimde "giriş" bölümü olarak kullandıklarını ve sosyal medyadan sonra tüketicilerle telefonla görüşülmesinin daha samimi, sıcak ve yanlış anlaşılmaya daha az müsait olduğunu 
belirtmiştir. Diğer taraftan K2, sosyal medya yönetiminde tüketiciler ile hızlı bir şekilde iletişime geçmenin, kendi ellerinde olan ve tüketicinin sinik tutumunun oluşmasını önlemeye yardımcı olabilecek bir durum olarak değerlendirmiştir. Ancak burada tüketiciyi ikna edebiliyor olmanın gerekli olduğunu belirten K2, bazen tüketicilerin ön yarg11 ya da kötü niyetli olabildiklerini ifade etmiştir. Buna ek olarak K2, sosyal medyada sinik tutum sonucu oluşacak direnişi nötralize edebilmek için hemen tüketicilerden özür dilediklerini ve onları çağrı merkezine yönlendirdiklerini belirtmiştir. Gerekirse bir firma yöneticisinin tüketiciyi aramasını ya da bir bayinin tüketiciyi ziyaret etmesini sağladıklarını ve tüketicinin maddi zararını karşıladıklarını söylemiştir. Ayrıca Facebook'ta tüketicilere ne kadar hızlı dönüş yapılırsa o kadar başarılı ve hızlı olduklarını gösteren bir bölüm olduğunu belirten $\mathrm{K} 2$, bu bölümde başarılı olma motivasyonunun bile markanın hızlı cevap vermesine sebep olduğunu ifade etmiştir.

\section{Tartışma, Sonuç ve Öneriler}

Yapılan literatür incelemesi sonucunda elde edilen veriler, sosyal medya uzmanlarının görüşlerine dayalı olarak gerçekleştirilen bu çalışmadaki bulgularla benzerlikler göstermektedir. Bu bakımdan daha önce yapılan çalışmaları destekler niteliktedir. Çalışmada; marka ve tüketici arasındaki ilişkinin yürütülmesine, sosyal medyada markanın sinik tutuma yönelik yaklaşımlarına, sosyal medyada markanın sinik tutum ortaya ç1kmadan ve çıttıktan sonra gösterdiği çabalara ilişkin veriler, İstanbul'da gida sektöründe faaliyet gösteren iki markanın sosyal medya uzmanlarının görüşleri doğrultusunda ortaya konulmuştur.

Derinlemesine görüşmeye katılan her iki markanın da gıda sektöründe başarılarını kanıtladığı ve hem ulusal hem de uluslararası pazarlarda varlı̆̆ını sürdürdüğg̈ görülmektedir. Yapılan araştırmada marka ile tüketici arasındaki ilişkilerin kalitesi konusunda en belirleyici faktörlerin 'güven' ve 'şeffaflık' olduğu ifade edilebilir. Bununla birlikte, tüketicilerle olan ilişkilerin kalitesini arttırmada K1 en iyiyi, en yeniyi en önce sunmak, tüketici araştırması yaparak ihtiyaç ve beklentileri karşılamak, onları anlamak, mutlu etmek, onlarla olan bağlar1 güçlendirmek gibi konular üzerinde dururken K2 tüketicileri dinlemek, önemsendiklerini hissettirmek, tüketicilerin marka ile ilgili yaşadıkları olumsuz deneyimi kendileriyle paylaştıklarında hızlı bir şekilde onlarla iletişime geçmek gibi konulara vurgu yapmışır. Diğer yandan, marka ile tüketiciler arasındaki ilişkilerin kalitesinin artması K1 tarafından markalarına; pazar payında artış, yatırımcı gözünde yatırım yapılmaya değer bir şirket olarak konumlandırılma, sürdürülebilir karlılık ve büyüme, ürünlerin kalitesini ve rekabet güçlerini geliştirme gibi katkılar sağladığı, K2 tarafindan ise markalarına sosyal medya uzmanlarını motive etme açısından katkı sağladığı belirtilmiştir. Öte yandan K1, tüketici tatmini ile birlikte gelen büyük pazar payının rakiplerini daha iyi olmak için çalışmaya teşvik ettiğini ve onların dönüşümüne katkıda bulunduğunu vurgulamışır. Bununla birlikte K1, rakipler karşısında avantaj sağlamak için de yenilikçi süreçler geliştirerek firmanın faaliyetlerini daha verimli hale getirdiklerini, ürün yelpazelerini genişlettiklerini ve sürdürülebilirliği iş yapış biçimlerinin ayrılmaz bir parçası olarak gördüklerini açıklamıştır. K2 ise rakipler ile doğrudan ya da dolaylı bir şekilde ilişki içinde olmadıklarını belirterek tüketiciler ile mümkün olduğu kadar en hızlı bir şekilde iletişime geçmenin, onları anlamaya, dinlemeye, önemsemeye ve takip etmeye çalışmanın rakipler karşısında avantaj sağladığını ifade etmiştir.

Derinlemesine görüşmeye katılan katılımcların her ikisinin de sosyal medyanın gücünün farkında oldukları görülmektedir. Tüketicinin sosyal medyayı etkin kullanması ile birlikte markalar da belirli stratejiler geliştirmiştir. Bu bağlamda her iki katıllımcı da sosyal medyada markaları ile tüketiciler arasında karşlıklı etkileşim ve güven duygusu oluşturmak için samimi bir dil kullanmanın önemli olduğunu vurgulamıştır. Bununla birlikte sosyal medya iletişimlerinde hazırlamış oldukları sosyal medya yönetim kılavuzundan yararlandıklarını belirten K1, gerekli durumlarda danışmak ya da onay almak için yönetim kurulu ile iletişime geçtiklerini ifade etmiştir. Aynı zamanda sosyal medyada paylaşlan bir içeriğin krize dönüşme riski ve krize dönüştüğünde oluşturacağı etki düşünülerek önceden hazırlıklı olduklarını anlatan $\mathrm{K} 1$, bunun krizin oluşumunu ya da büyümesini engellemede ve bazı durumlarda krizi firsata çevirmede kullanılabilecek en önemli avantaj olduğunu belirtmisstir. Sosyal medyanın kontrol altına alınabilmesinin oldukça zor ancak gözlemlenebilir olduğunu söyleyen K2 ise, tüketicilerin kendilerine hızlı dönüş yapılmaması ya da şikayetlerinin giderilmemesi konusunda sergiledikleri sinik tutumları gözlemlediklerini vurgulamıştır. Gerek reklam mesajlarının içeriği gerekse reklamlarda kullanılan dil açısından K1, tüketicilere özellikle de çocuklara yönelik olarak sorumlu beslenme prensiplerine uygun vaatlerde bulunmaya özen gösterdiklerini, K2 ise samimi olduğu kadar güven veren bir dil kullanmaya çalıştıklarını açıklamıştır. Ayrıca her iki katılımc1 da reklamlar konusunda tüketicinin görüş, yorum ve önerilerini dikkate aldıklarını söylemiştir. Sinik tutum sebepleri arasında görülen reklam iletişiminde aldatıcılık konusunda K1, 
reklam hukukunun bilinmesi ve geliştirilmesinin zorunluluk olduğunu vurgularken K2 ise markaların reklam iletişimlerinde eskisinden çok daha fazla dikkat etmeleri gerektiğini ve toplumun bazı kesimlerini kızdırabilecek iletişimlerden kaçınmanın yararlı olacağını belirtmiştir.

Derinlemesine görüşmeye katılan K1, sosyal medyada markalarına yönelik sinik tutumların tespiti ile ilgili olarak bir ajansla çalıştklarını, K2 ise "monitoring" adı verilen dinleme ve takip yazılımları kullandıklarını ifade etmiştir. Bununla birlikte K1, tüketicilerle aralarındaki güven duygusunu pekiştirmek için ürünlerinin tamamında Türk Gıda Kodeksi Etiketleme Yönetmeliği gereğince gidanın içeriğine, niteliğine ve üretimine yönelik verileri şeffafça paylaştıklarını ve tüketici geri bildirimlerini kayıt altına alarak değerlendirdiklerini, gerekli düzenlemeleri yaptıklarını açıklamıştır. K2 ise sosyal medya hesaplarına gelen her mesajı mutlaka cevapladıklarını, olumsuz yorumları silmediklerini, sosyal medyayı iletişimde "giriş" bölümü olarak kullandıklarını ve sosyal medyadan sonra tüketicilerle telefonla görüşülmesinin daha samimi, sıcak ve yanlış anlaşılmaya daha az müsait olduğunu belirtmiştir. İletişimin ilk adımının dinlemek olduğunu vurgulayan $\mathrm{K} 1$, sosyal medyada markalarına yönelik sinik tutumları önlemek için tüketicilerden gelen önerileri, geri bildirimleri önemsediklerini, insanlarla ilişkilerinde saygılı ve yapıcı davrandıklarını, insan ve hayvan haklarını, cinsiyet eşitliğini, demokrasinin temel değerlerini gözettiklerini, doğruluğundan emin olmadıkları bilgileri paylaşmadıklarını, telif haklarına ve etik kurallara uyduklarını; K2 ise tüketiciler ile hızlı bir şekilde iletişime geçmenin ve onları ikna edebiliyor olmanın gerekli olduğunu ifade etmiştir. Tüm bunlara ek olarak, sosyal medyada sinik tutum sonucu oluşacak direnişi nötralize edebilmek için K1, medya ve pazarlama iletişimi yönetim ekiplerinin, sosyal medya yönetim kurulu ile dayanışma içinde olduğunu, yaşanan durumla ilgili risk analizini doğru yapabilmek ve hızlı çözümler üretebilmek için birimlerle her zaman iletişim içinde oldukların, K2 ise tüketicilerden hemen özür dilediklerini ve onları çağrı merkezine yönlendirdiklerini belirtmiştir. Gerekirse bir firma yöneticisinin tüketiciyi aramasını ya da bir bayinin tüketiciyi ziyaret etmesini sağladıklarını ve tüketicinin maddi zararını karşıladıklarını ifade etmiştir.

Bu çalışmanın, markaların sosyal medyada oluşan tüketici sinizmine daha fazla önem vermeleri ve sinik tutumlara yönelik ne gibi yaklaşımlarda bulunduklarının anlaşılması açısından önemsenebilecek bilgiler içerdiği söylenebilir. Elde edilen bulguların, ulusal veya uluslararası markalara faydalı olacağı düşünülmektedir. Bunun yanı sıra, bu çalışmada elde edilen bulgular, araştırmanın örneklemi ile sınırlıdır. Ancak ileride yapılacak çalışmalara ışık tutması bakımından önemli sonuçlar içerdiği düşünülmektedir.

Gelecekte buna benzer yapılacak çalışmalarda, kültüre göre değişebilecek olan sosyal medyada oluşan sinik tutum ve bu tutuma yönelik markaların yaklaşımları farklı değerlendirilebileceği için uluslararası düzeyde karşılaştırmalı çalışmalara yer verilmesi, konunun daha iyi anlaşılması ve açıklanması bakımından oldukça yararlı olacaktır. Bununla birlikte markalara yönelik sosyal medyada oluşan sinik tutumlar daha temsili örneklemler kullanılarak ileri araştırmalarla derinlemesine test edilebilir. Ayrıca, markalara yönelik sosyal medyada oluşan sinik tutumlar için ölçek geliştirilebilir.

\section{Kaynakça}

Akbayır, Z. ve Kuşay, Y. (2015). Sosyal medyadan krize bakış: Otomotiv sektöründe kriz dönemlerinde sosyal medyanın kullanımına ilişkin bir araştırma.International Journal of Social Sciences and Education Research, 1(3), 972985.

Marketing Türkiye(2017). A.L.F.A. markalar görkemli bir törenle ödüllerine kavuştu.Erişim adresi: https://www.marketingturkiye.com.tr/haberler/a-l-f-a-markalar-gorkemli-bir-torenle-odullerine-kavustu/

Andersson, L. M. (1996). Employee cynicism: An examination using a contract violation framework. Human Relations, 49(11), 1395-1418.

Andersson, L. M. ve Bateman, T. S. (1997). Cynicism in the workplace: Some causes and effects.Journal of Organizational Behavior, 18, 449-469.

Aron, D. (2001). Consumer grudgeholding: Toward a conceptual model and research agenda, Journal of Consumer Satisfaction, Dissatisfaction and Complaining Behaviour, 14, 108- 119.

Bakır, U. ve Çelik, M. (2013). Tüketim toplumuna eleştirel bir yaklaşım: Kültür bozumu ve yıkıcı reklamlar.Selcuk Iletisim Dergisi,7(4), 46-63.

Bal, H. (2013). Nitel araştırma yöntemi. Isparta: Fakülte Kitabevi.

Bat, M. ve Yurtseven, Ç. T. (2014). Sosyal medyada kurumsal kriz yönetimi: Onur Air örneği. Gümüshane Üniversitesi Illetisim Fakültesi Elektronik Dergisi, 2(3), 197- 223.

Canbazoğlu, A. D. (2017). Farklı marka sadakat düzeylerindeki tüketicilerin olumsuz kulaktan kulağa iletişimi yayma davranışları. Inönü Üniversitesi İletişim Fakültesi Elektronik Dergisi, 2(1), 135-156.

Cheng, S., Lam, T. ve Hsu, C. H. C. (2006). Negative word of mouth communication intention: A application of the theory of planned behavior. Journal of Hospitality \& Tourism Research, 1, 95-116.doi: 10.1177/1096348005284269 
Chylinski, M. ve Chu, A. (2010). Consumer cynicism: Antecedents and consequences.European Journal of Marketing, 44(6), 796-837.

Copleston, P. (1993). A history of philosophy. New York: Image Books Doubleday.

Cova, B. ve D'antone, S. (2016). Brand iconicity vs. anti- consumption well-being concerns: The Nutella palm oil conflict.The Journal of Consumer Affairs, 50(1), 166-192.

Çă̆sal, V. (2011). Deprem ve sosyal medya yankılar, Erişim adresi: http://t24.com.tr/yazarlar/volkan-cagsal/deprem-vesosyal-medya-yankilari-4269

Çetin, M. ve Toprak, Y. E. (2016). Kriz iletişimi ve sosyal medya: Emisyon krizinde Volkswagen'in Facebook kullanımı.Selçk İletişim Dergisi, 9(3), 54-68.

Çetinkaya, Ö. A. ve Ceng, E. (2018). Türkiye'deki Black Friday etkinliğinin tüketici sinizmi bağlamında bir değerlendirmesi. MANAS Sosyal Araștrmalar Dergisi,7(4), 167-180.

Çubukçuoğlu, H. F. (2017). Kurumsal kuram penceresinden halkla ilişkiler: Nestle ve palm yağ1 krizi. İletişim Kuram ve Arasterma Dergisi, 44, 173- 192.

Esener, A. (2017). Markalarn yaşadiğ olumsuz olaylarn online medyada krize dönüsmesi ve otomotiv sektörüne yönelik bir araștrma (Yüksek Lisans Tezi). Doğuș Üniversitesi Sosyal Bilimler Enstitüsü, İstanbul.

Güven, E. (2016). Tüketimde sinik tutum: Tüketici sinizminin sebep ve sonuçları. Isşletme Araştırmalar Dergisi-journal of Business Research, 8(2), 152-174.

Helm, A. (2004). Cynics and skeptics: Consumer dispositional trust. In B. E. Kahn ve M. F. L. Valdosta (Eds.),.Advances in consumer research. GA: Association for Consumer Research, 31(1), 345-351.

Hogg, M. A. ve Vaughan, G. M. (2011). Sosyal psikoloji(Çev: İ. Yılmaz ve A. Gelmez (2. Basım).Ankara: Ütopya Yayınevi.

İnceoğlu, M. (2004). Tutum algz iletişim. Ankara: Elips Kitap.

Kalağan, G. ve Güzeller, C. O. (2010). Öğretmenlerin örgütsel sinizm düzeylerinin incelenmesi. Pamukkale Üniversitesi Eg̈itim Fakültesi Dergisi, 27, 83-97.

Kavak, B. (2013). Pazarlama ve pazar araștırmalar: Tasarm ve analiz. Ankara: Detay Yayıncıllk.

Kirk, J. ve Miller, M. L. (1986). Reliability and validity in qualitative research. Beverly Hills, CA: Sage.

Kucuk, U. S. (2007). Negative double jeopardy: The role of anti-brand sites on the internet. Journal of Brand Management, 15, 209-222.

Kurtuluş, K. (2010). Araştırma yöntemleri, İstanbul: Türkmen Kitabevi.

BBC TURKISH (2005). Nike'den 'seffafllk' raporu. Erişim adresi: http://www.bbc.co.uk/turkish/news/story/2005/04/ 050413_nike_report.shtml

Özler D. E., Atalay, C. G. ve Şahin, M. D. (2010). Örgütlerde sinizm güvensizlikle mi bulaşır? Organizasyon ve Yönetim Bilimleri Dergisi,2(2), 47-57.

Özpeynirci, E. (2017). Emisyon skandalı otomotiv devine pahalıya patlad1, Hürriyet Gazetesi, Erişim adresi: http://www.hurriyet.com.tr/ekonomi/abdde-yer-gok-volkswagenin-geri-aldigi-araclarla-dolmaya-basladi40429859

Patton, Q. M. (1990). Qualitative evaluation and research methods. London: Sage.

Persson, L. (2008). Ethics and environment in the coffee sector-linking CSR to the consumer's power in the context of sustainable development.Faculty of Social and Life Sciences Department of Environment and Health. D-level Degree Project Honours Program in Environmental Science.

Sandıkc1, Ö. ve Ekici, A. (2009). Politically motivated brand rejection. Journal of Business Research, 62, 208-217.

Tosun, N. (2017). Marka yönetimi, 3. Baskı, İstanbul: Beta Basım Yayım Dağıtım A.Ş.

Tosun, N. B., Uraltaş, N. T., Nas, A., Özkaya, B., Güdüm, S., Ertürk, B., Dönmez, M., Çerçi, M., Ülker, Y., Cesur, D. K., Varol, E. ve Kiçir, İ. (2018). Reklam yönetimi. İstanbul: Beta Basım Yayım Dağıtım A.Ş.

Tutar, H. (2012). Sosyal psikoloji İstanbul: Seçkin Yayınc1lık.

Türnüklü, A. (2000 Güz). Eğitimbilim araştırmalarında etkin olarak kullanılabilecek nitel bir araştırma tekniği: Görüşme. Kuram ve Uygulamada Eğitim Yönetimi, 24(24), 543-559.

Yıldırım, A. ve Şimşek, H. (2011). Sosyal bilimlerde nitel araştırma yöntemleri. Ankara: Seçkin Yayıncılık.

\section{EXTENDED ABSTRACT}

Negative feelings of people, such as anger, resentment, and dissatisfaction are known to be reflected in their consumption behaviors. In this context, the negative experiences that are experienced with the brand and the unethical behavior of the brand cause the consumer to exhibit cynical attitudes towards that brand. Thanks to the fast and easy access of social media, the consumer is able to share the negative experience with the brand with other consumers and this can cause the brand to fall into a crisis. This study aims to reveal the approaches of brands towards cynical attitude in social media. For this purpose, in-depth interviews were conducted with social media experts of two brands operating in the food sector in Istanbul and a judgment sampling method was used. The data obtained as a result of the literature review show similarities with the findings in this study, which was conducted based on the views of social media experts. In this respect, it supports the previous studies. In the study, data on the conduct of the relationship between brand and consumer, the brand approach to cynic attitude on social media and the 
efforts of the brand before and after the emergence of cynic attitude on social media are presented in line with the opinions of social media experts of the two brands operating in the food sector in Istanbul. Since the participants did not give permission to disclosure of company names during in-depth interviews, the company names remain anonymous and the participants were labeled as K1 during the first meeting and as $\mathrm{K} 2$ during the second meeting.

In the research, it can be stated that 'trust' and 'transparency' are the most determining factors regarding the quality of relations between the brand and the consumer. However, in improving the quality of relationships with consumers, $\mathrm{K} 1 \mathrm{emphasized} \mathrm{the} \mathrm{need} \mathrm{to} \mathrm{present} \mathrm{the} \mathrm{best,} \mathrm{the} \mathrm{newest} \mathrm{product} \mathrm{as} \mathrm{soon}$ as possible, meeting the needs and expectations by doing consumer research, understanding the consumers, making them happy, strengthening ties with them; while K2 emphasized the actions such as listening to consumers, making them feel cared for and contacting them quickly when consumers share their negative experience with the company. On the other hand, increasing the quality of the relations between the brand and the consumers has been interpreted by $\mathrm{K} 1$ as a benefit to the company in terms of increase in market share, positioning as a company worth of investing in the eyes of the investor, sustainable profitability and growth, improving the quality and competitiveness of products while $\mathrm{K} 2$ has interpreted this as a benefit to motivate social media experts. On the other hand, K1 has emphasized that the large market share that comes with consumer satisfaction encourages competitors to work in order to be better and contributes to their transformation. In addition, K1 has explained that they have developed innovative processes to take advantage of competitors, making the company's operations more efficient, expanding their product range and seeing sustainability as an integral part of the way they do business. K2 has stated that they are not in a direct or indirect relationship with competitors and that contacting consumers as quickly as possible gives them the advantage of trying to understand, listen to, care for and follow them, differentiating them from their competitors.

In-depth interview participants observed that both of the companies were aware of the power of social media. With the consumers' efficient use of social media, the brands have also developed new strategies. In this regard, both participants have emphasized that it is important to use friendly language on social media to build a sense of mutual interaction and trust between their brands and the consumers. However, K1 has stated that they have benefited from the social media management guidance that they have prepared in social media communications and have contacted the board of directors to consult or obtain approval where necessary. In addition, $\mathrm{K} 1$ has stated that they are aware of the fact that the content shared on social media is at risk of leading into a crisis and they are prepared for it and added that this knowledge is in fact an important asset to prevent turning this crisis into an opportunity. K2 explains that it is very hard but also an observable notion that the social media can be controlled and emphasized that the consumers are observing cynical attitudes about not returning to them quickly or solving their complaints. In terms of both the content of the advertising messages and the language used in the advertisements, $\mathrm{K} 1$ explained that they are careful to make promises to consumers in accordance with the principles of responsible nutrition, especially for children, while K2 is trying to use a language which is both confident and sincere. In addition, both participants have stated that they considered the consumer's opinions, comments and suggestions regarding the ads. In terms of deceptiveness in advertising communication, which is one of the reasons of cynic attitude, $\mathrm{K} 1$ has emphasized that it was mandatory to know and improve the advertising law while $\mathrm{K} 2$ has stated that the brands need to pay attention to advertising communication more than ever and that it would be beneficial to avoid communications that could anger some segment of society.

In in-depth interview, K1 stated that they worked with an agency regarding the determination of cynical attitudes towards their brands on social media, while K2 used listening and tracking software called "monitoring". However, K1 explained that in order to reinforce the feeling of trust between them and the consumers, they transparently share the data regarding the content, nature and production of food in accordance with the Turkish Food Codex Labelling Regulation and they evaluate the consumer feedback by logging and making necessary arrangements. K2 stated that they certainly reply to every message coming to their social media accounts and never delete negative comments; that they use social media as an "introduction" method in communication and that it is more convenient, friendly and less prone to misunderstanding to interview customers over the telephone after social media. Emphasizing the first step of communication as listening, $\mathrm{K} 1$ has stated that in order to prevent cynical attitudes towards brands in social media, they consider the feedback from consumers, that they behave respectfully and constructively 
in their relationships with people, that they observe human and animal rights, gender equality, main values of democracy and that they do not share inaccurate information. K2 has stated that it is necessary to communicate quickly with the consumers. In addition, $\mathrm{K} 1$ has stated that the media and marketing communication management teams are in solidarity with the social media management board in order to neutralize the resistance caused by cynical attitudes in social media, that they are always in contact with the units in order to be able to perform the risk analysis of the situation and produce quick solutions. K2 has indicated that they always apologize to consumer immediately and that they direct them to call center. K2 added that when necessary, a company manager calls the consumer or assigns a dealer to visit the consumer and that they compensate the consumer's financial loss.

It can be said that this study contains information that may be important for brands to pay more attention to the consumer cynicism that is present on social media and to understand what approaches they may take towards these attitudes. The results of this study are important in terms of showing what kind of approaches the brands should take in face of the cynical attitudes that occur in social media and the approaches that should be taken in line with these attitudes. In addition, the study aims to shed light on both national and international brands that face the cynical attitudes in social media, and this study will establish a baseline for the future studies, thanks to its novel subject-matter. 